\title{
Marcos e narrativas correntes de uma Lisboa Pombalina
}

Current Milestones and Narratives

of a Pombaline Lisbon

Gustavo Pereira*,**

RESUMO

$\mathrm{O}$ artigo apresenta um breve percurso crítico-reflexivo pela região central de Lisboa, cidade que constrói, preserva e cultiva uma herança percebida como pombalina. $\mathrm{O}$ autor se atenta à conformação de marcos, narrativas e usos de aspectos de um passado ligado ao marquês de Pombal. Tomam-se como foco o Lisboa Story Centre, as tentativas de fazer da Lisboa Pombalina Patrimônio Mundial da UNESCO e a praça do Comércio; espaço vinculado ao discurso mais difundido sobre a reconstrução da capital após o terremoto de 1755 - discurso duradouro que se remete, no fundo, às ideias e justificativas elaboradas e divulgadas pelo marquês e por seus colaboradores.

Palavras-chave: Cidade-patrimônio; documento/monumento; usos do passado.

\begin{abstract}
The paper presents a brief critical-reflective journey through the central region of Lisbon, a city that builds, preserves, and cultivates a heritage perceived as Pombaline. The author draws attention to the conformation of milestones, narratives, and uses of aspects of a past connected to the Marquis of Pombal. The article focuses on the Lisboa Story Centre, the attempts to make Lisboa Pombalina an UNESCO World Heritage Site, and the Praça do Comércio; a space linked to the most widespread discourse about the reconstruction of the capital after the 1755 earthquake - a long-lasting discourse that refers, in essence, to the ideas and justifications elaborated and disseminated by the Marquis and his collaborators.
\end{abstract}

Keywords: Heritage city; Document/ monument; Uses of the past.

\footnotetext{
* Universidade NOVA de Lisboa (UNL), Lisboa, Portugal. gustavopereira@fcsh.unl.pt <https://orcid. org/0000-0003-0227-2643>

** Investigador Integrado Doutorado do CHAM - Centro de Humanidades (CHAM - NOVA FCSH). O presente trabalho foi realizado com apoio da Coordenação de Aperfeiçoamento de Pessoal de Nível Superior - Brasil (CAPES) - Código de Financiamento 001.
} 
A cidade pombalina ficou com os seus arruamentos da Baixa, com o seu cais das Colunas, com o seu terreiro do Paço e com o seu arco da rua Augusta. Tal tem sido o único plausível pretexto para consagrar ao marquês de Pombal outro monumento, além do que já significa a memória do terreiro do Paço. Ao reedificador de Lisboa, a cidade agradecida. Toda a apoteose que ultrapasse o limite desse restrito programa [...] não deve ser objeto de uma obra de arte pública, porque o fim desse elevado ramo de arte é dar ao povo um eterno e intangível tema de reflexão, de ensino, de simpatia e de concórdia absoluta, e não suscitar desavenças e transmitir rancores de gerações mortas a gerações que vivem sem uma necessidade demonstradamente urgente de históricos pontapés.

Ramalho Ortigão, 1934 [1914].

\section{MEMÓRIAS DA CIDADE}

Lisboa. Na praça/rotunda do Marquês de Pombal, uma estátua (1934) representa o marquês olhando a urbe desde o topo da avenida da Liberdade (1879). Ao longe, lá embaixo; no espaço mais emblemático (praça do Comércio) do centro histórico lisboeta (Baixa Pombalina), vê-se uma estátua equestre (1775) que representa D. José (1750-1777) miFigura 1 - Painel do Lisboa Story Centre. rando o cais das Colunas, o rio Tejo e Cacilhas. No pedestal, há um medalhão com uma efígie de Pombal. Ao fundo, no arco da rua Augusta (1875), veem-se nove estátuas, sendo uma do marquês. A meio da praça, um painel o evoca com o convite: "Viaje até a época pombalina. Visite o Lisboa Story Centre e descubra a visão inovadora que reconstruiu Lisboa" (figura 1).

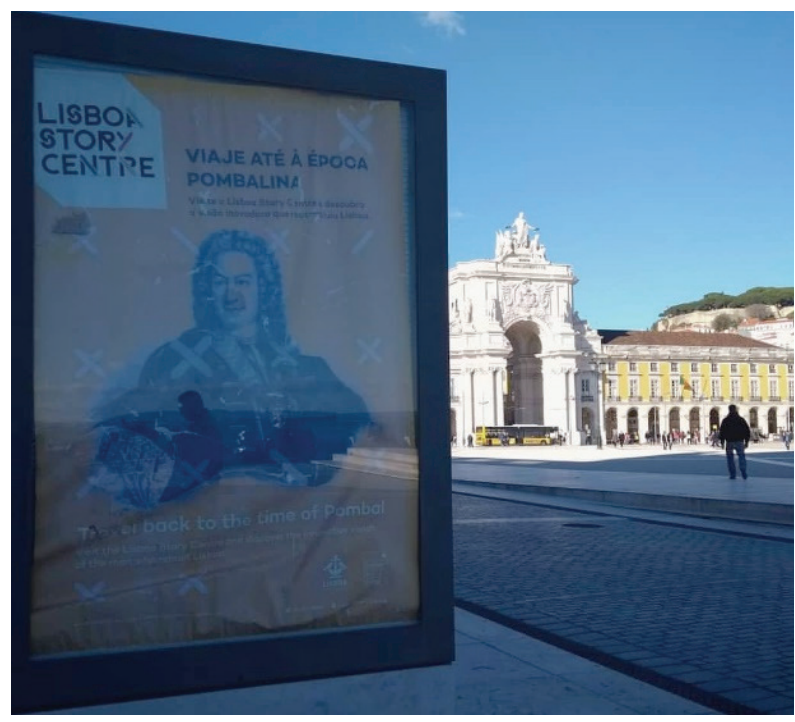

Fonte: Fotografia do autor (18 jan. 2018). 
Inaugurado em 2012, o Lisboa Story Centre afirma ser uma "plataforma de conhecimento e interactividade que, inspirada nos factos e eventos que moldaram Lisboa - com particular enfoque no terramoto de 1755 e nos planos da Baixa Pombalina -, convida o visitante a descobrir o património de forma lúdica e interactiva" (Lisboa Story Centre, memórias..., 2012). Resultado de uma parceria entre a Associação Turismo de Lisboa e o Turismo de Portugal ${ }^{1}$ - com um investimento de 3 milhões de euros, viabilizando o "projeto-âncora do novo terreiro do Paço" ("Lisboa Story Centre” inaugurado..., 2012) -, trata-se de um espaço “inovador” que

desperta vários sentidos e dá a sentir alguns dos factos mais relevantes [...] sobre a rica e intensa história de Lisboa. Uma forma de interagir com Lisboa [...]; proporciona uma experiência de visita singular às memórias da cidade (Visão - Posicionamento - Promessa, s. d.).

O visitante irá viajar no tempo como se percorresse um livro ilustrado trazido à vida. Através do uso de cenografia, multimédia e experiências sensoriais, são apresentados relatos dramáticos dos principais eventos [...] de uma forma lúdica e interactiva, respeitando, porém, a verdade histórica (Memórias da Cidade - O que é?, s. d.).

Duas de suas seis áreas temáticas se relacionam à segunda metade do século XVIII, sob a perspectiva da influência de Pombal. Anuncia-se, assim, que o visitante "será envolvido nos acontecimentos do trágico dia de Todos os Santos de 1755 e viverá a experiência imersiva do terramoto e das suas consequências". Dado que o marquês "compareça" por via holográfica, o visitante "participará depois com o marquês de Pombal na visão inovadora da reconstrução da cidade em termos urbanísticos e de organização". O Story Centre ocupa um prédio requalificado na praça do Comércio e exibe versões sobre acontecimentos e personagens conhecidos no discurso histórico mais difundido sobre a capital portuguesa. Expondo "do passado ao presente os principais eventos", constrói a imagem de uma cidade culturalmente diversa, historicamente rica e com traçado urbanístico moderno e inovador, instruindo e entretendo estudantes e turistas; possibilitando-lhes "despertar" sensações, "interagir" com a cidade e "visitar" suas memórias (Memórias da Cidade - O que é?, s. d.).

No sexto núcleo, mostra-se "a maqueta da Baixa Pombalina, que possibilita a interação multimédia com variados acontecimentos”. Explora-se "a arquitetura da cidade e se proporciona a descoberta mais pormenorizada da sua história, incentivando a sua descoberta na atualidade". Apresentam-se curiosi- 
dades sobre episódios decorridos no passado e sobre a região no presente (Memórias da Cidade - O que é?, s. d.). Desenvolvem-se, por fim, sessões de "História ao Vivo"; performance que "simula aquilo que seria a oportunidade de encontrar, nos dias de hoje [...], através de uma conversa informal, [...] personagens históricas à escolha" - como o marquês (Gostava de perguntar alguma..., 2017). Propõem-se, pela representação teatral, "o contato e o diálogo com uma personagem da história da cidade de Lisboa, que partilha memórias sobre a sua vida e sobre a cidade e o país" (Programa para escolas, s. d.)².

A ideia de um "centro interpretativo da Baixa Pombalina" é sugerida em 2004 pelo arquiteto João Mascarenhas Mateus (2004a), que propõe um espaço

que permita um percurso guiado ao longo da história deste sítio histórico. Um centro que recorra às novas tecnologias, incluída a da realidade virtual, com auxílio da fotografia, de filmes e documentários históricos, gravações de áudio que ajudem a uma transposição temporal e espacial do visitante.

Coordenador técnico da candidatura da Baixa à Lista do Patrimônio Mundial da UNESCO, Mateus se dedica a atividades relacionadas ao dossiê demonstrando o Valor Universal Excepcional da região ${ }^{3}$. Nesse ensejo, quer "atrair a atenção para este valor da Memória que está na base da riqueza e da importância da Baixa Pombalina, para Portugal e para a Humanidade". Para ele, importa tornar a Baixa

um pouco mais nossa. Fazer com que a Memória passe a estender-se, a partir do evento, à estrutura espacial, às formas territoriais e à vida quotidiana. A Baixa Pombalina, na sua monumentalidade, apresenta um manancial de qualidades evocativas e como tal constitui um lugar de Memória e para a Memória, baseando-se sempre sobre eventos históricos que devem ajudar ao estabelecimento de um diálogo que estimule o conhecimento e a apreensão dos seus valores como sítio histórico-monumental (Mateus, 2004b).

A entrada de Lisboa na Lista Indicativa de Portugal se deu em 2004. Desde 2016, contudo, a cidade conta com duas inscrições nessa etapa inicial e local do processo. Na primeira (Lisboa Pombalina), destaca-se o enfoque pombalino. Mas também na segunda, mais abrangente, fluida e cosmopolita (Lisboa Histórica, Cidade Global), recorre-se às ideias de inovação e modernidade (que caracterizariam a reedificação pombalina) para comprovar o Valor Universal Excepcional ${ }^{4}$, identificando 
o palimpsesto da cidade, reconhecível nas diferentes camadas territoriais e culturais de uma urbe em permanente transformação. Dessa evolução [...], resulta a Lisboa Histórica, singular entrelaçado de tecidos urbanos, testemunho de uma história milenar de intercâmbio de culturas, povos e religiões. Realça dois momentos da cidade que constituíram marcos decisivos na sua evolução - os Descobrimentos, no século XV, e o Terramoto de 1755 - momentos em que a cidade se atualizou adotando as correntes do pensamento inovador da Europa. A cidade medieval cresceu até ao rio e transformou-se na Cidade Global, que mais tarde se reconstruiu como iluminista (Candidaturas à UNESCO, 2017).

Quanto ao Story Centre (referido na primeira candidatura), mesmo que se evite descrevê-lo como museu histórico, sua proposta traz à tona tais instituições (Almeida, 1993; Black, 2011; Knauss, 2018). Ulpiano Bezerra de Menezes (1994) destaca a função documental desses museus, que, mais que preservar e exibir objetos do passado, devem problematizá-los, desvendando suas "construção, transformações e funções [...], trilhando o caminho inverso [ao] da fetichização, isso é, partindo do objeto para a sociedade”. Já os living museums (próximos da História ao Vivo) são "casos particulares de reconstrução e contextualização históricas” (Menezes, 1994, pp. 27 e 33). Partem de uma noção de passado como substância em si, abordável sem mediações e reproduzível no presente por meio de dispositivos que apelam à teatralidade e à performatividade ${ }^{5}$. Nesse sentido, o visitante, alegadamente capaz de retornar ao passado,

se incompatibiliza, por isso mesmo, com o conhecimento, pois se anulam as distâncias [...]; processo profundamente antipedagógico, pois nos aprisiona no presente e, incapaz de nos fazer compreender a alteridade no que ela tem de específico, transforma esse presente no único termômetro capaz de tudo medir (Menezes, 1994, p. 35).

O historiador ressalta, por oposição, tanto o acesso mediado às representações do passado quanto a problematização de seus vestígios - feitos documentos a partir de seleção, preservação e crítica. Daí a se contraporem suas palavras aos anúncios do Centro de Interpretação Histórica, os quais propõem vivências, sensações e diálogos diretos com simulações de um passado que se busca exaltar, assimilando-o acriticamente ao presente.

A despeito de toda a propaganda focar em recursos “inovadores”, a história que lá se propõe contar não apresenta tantas problematizações. Quanto ao 
marquês, como costuma ocorrer quando se busca representá-lo de modo consensual, ele é ressaltado por sua "visão inovadora que reconstruiu Lisboa" (painel LSC); considerado personagem-símbolo de uma cidade que se pretende inovadora, iluminista e moderna ${ }^{6}$. Ademais da seleção do que lá se expõe sobre o período pombalino (que minimiza ou não se refere ao seu caráter polêmico), não se problematizam os anacronismos de tais representações. Nota-se, pois, o interesse atualizado por determinadas narrativas e por aspectos específicos daquilo que o período histórico evocado por Pombal traz à tona em Lisboa.

A capital se vale de uma alegada modernidade de seu passado (recordado e representado a partir da figura recortada/construída do marquês) para se afirmar como excepcional, atrativa e relevante em um contexto de competitividade interurbana. Em questão, o recurso à cultura como forma de promover o desenvolvimento social e econômico da cidade; percepção que desde a década de 1980 vem orientando a atuação de políticos, gestores e planejadores urbanos (Arantes, 1998; Ferreira, 2010). A aposta na construção de novos equipamentos culturais e a promoção de políticas patrimoniais se inserem nesse processo.

O Centro de Interpretação Histórica se situa na praça do Comércio; espaço monumental em que o governo pombalino se fez representar ao centro simbólico da capital que se reconstruía. Espaço em que se baseiam, além disso, propostas correntes para classificar Lisboa como Patrimônio Mundial, o que conferiria à praça e à urbe um valor diferencial no mercado mundial de cidades ${ }^{7}$. É na lógica dessa dinâmica patrimonial que se deve considerar a escolha de espaços pretensamente capazes de evocar imagens-síntese das cidades; imagens construídas e difundidas também com o objetivo de atrair os fluxos globais de capital e de turistas (Sánchez, 2010 [2003]). Seletivas e parciais, tais imagens são frequentemente concebidas/conformadas a partir do recurso a aspectos de um passado imaginado e compartilhado.

No que diz respeito ao passado pombalino, recorda-se que Sebastião José de Carvalho e Melo foi nomeado secretário de Estado dos Negócios Estrangeiros e da Guerra no início do reinado de D. José. Logo após o terremoto que destruiu parte de Lisboa, passou à secretaria do Reino (1756), mais importante, e coordenou medidas que marcaram o reinado e os discursos sobre o século XVIII português - como a reconstrução da capital, a expulsão dos jesuítas (1759) e a reforma da Universidade (1772). Em recompensa pelos serviços prestados à coroa, foi feito conde de Oeiras e marquês de Pombal. A despeito de o título mais elevado lhe ter sido concedido após os seus 70 anos, 
ficou por tal modo conhecido na posteridade (Azevedo, 1990 [1909]; Tavares, 2018).

Devido à sua grande influência, o período em que ele esteve à frente do governo recebeu o epíteto de pombalino; período associado a leituras divergentes sobre suas medidas políticas e também sobre a violência com que lidou com opositores, bem como a conflitos de memória (Pollak, 1989) que fazem dele um dos tópicos históricos mais discutidos no país (Torgal, 1984). Segundo Sérgio Campos Matos (2010, p. 17), o marquês se tornou

uma das presenças mais marcantes na cultura histórica e até na cultura política portuguesa do século XIX [...]; sendo uma das personalidades mais controversas na memória nacional desde os fins do século XVIII [...]. Raras personalidades históricas em Portugal terão sido tão louvadas e, ao mesmo tempo, tão execradas.

Para Nuno Gonçalo Monteiro (2008 [2006], pp. 9-10), "não é pelo nome do rei que o [reinado] é, em regra, conhecido", mas, "quase sempre, pela interposta pessoa do seu ministro [...]; por força das celebrações encomiásticas e das críticas enfáticas que conheceu". De acordo com o historiador, "quase todos os decisores e opinadores políticos das décadas subsequentes tiveram de se debruçar sobre a sua herança, reiteradas vezes comentada também por políticos e viajantes estrangeiros" (Monteiro, 2008, p. 326). No que diz respeito ao pombalismo (Serrão, 1989), Joel Serrão (1984, p. 358) afirma: "parece evidente que o aspecto fundamental daquilo que [o] caracterizou [...] é exactamente o reforço da máquina do Estado”. Monteiro (2008 [2006], p. 326) ainda entende que o marquês,

contemporâneo das Luzes, partilhou com elas alguns inimigos - os jesuítas e o poder civil da Igreja - e foi buscar nelas algumas fontes de inspiração. Mas não era um produto do Iluminismo. [...] Foi exatamente pela imagem de ruptura que criou e pelos adversários que teve que o regime pombalino inaugurou uma herança política [...] sucessiva e contraditoriamente apropriada.

Na perspectiva de Heloísa Paulo (2010, p. 169), a memória oficial ou oficiosa de grandes vultos é uma construção efetuada a partir de valores institucionalizados; resulta de um trabalho de recorte em que se descartam, de sua trajetória "real e documentada", referências que fogem à imagem que se quer, a cada passo, afirmar. "Produto de uma memória social cristalizada [...], sofre 
os reveses da própria história, acompanhando as mudanças sociais, justificando as alterações políticas e ideológicas através dos tempos” ${ }^{8}$. Reflexão importante para pensar interpretações do passado pombalino.

Em discursos do governo do marquês, nota-se como a oposição por parte de jesuítas e setores da nobreza a suas medidas assumiu o aspecto de "justificações fundamentais na memória que o pombalismo vai construindo de si mesmo" (Tavares, 2018, p. 68). Na posteridade, a violência com que o ministro lidou com muitos opositores (principalmente os nobres supliciados a seu mando) tem sido continuamente recordada como acusação contra sua figura. Quanto às políticas antijesuíticas, trata-se do principal aspecto pelo qual o marquês (representado como político esclarecido e antirreacionário) foi mobilizado combativamente por setores liberais e republicanos nos séculos XIX e XX, o que ajuda a compreender a duradoura oposição a Pombal por setores tradicionalistas (Torgal, 1984; Matos, 2010; Abreu, 2004). A reforma dos estudos e principalmente a reconstrução de Lisboa, por outro lado, ainda que questionadas/relativizadas por alguns críticos, remetem àquilo que sua figura informa de menos conflituoso, sendo muito referidas, em termos elogiosos e exagerados; vinculando o marquês, enquanto ministro iluminado, a um ideal de racionalidade e modernidade - bem representado pelos planos da Lisboa pombalina.

\section{MARCOS COMEMORATIVOS}

Antes de avançar, ressalta-se a contribuição de Paul Ricoeur (2012 [1983]; 2018 [2000]) para este trabalho. Sejam suas reflexões sobre narrativa: a tese de que o tempo se torna humano na medida em que está articulado de maneira narrativa e a distinção entre narrativas ficcional e histórica a partir dos respectivos referenciais (imaginário e real); sejam suas reflexões sobre o fenômeno mnemônico: presença no espírito (representação) de uma coisa ausente; de uma realidade pretérita (o que não é mais, porém já foi).

Atenta-se, nestas páginas, a monumentos pombalinos destacados nos planos lisboetas de valorização/preservação contemporâneos. Foca-se menos no histórico que eles evocam (e no modo como tal evocação se manifesta) e mais em sua relação com os pósteros (Connerton, 1999 [1989]; Halbwachs, 2013 [1950]). Ao considerar tais marcos, ademais, indaga-se, com Miguel Faria (1994, pp. 51-52): ao cidadão contemporâneo, 
que leitura oferecem os itinerários urbanos percorridos na rotina do seu quotidiano? A cidade, dominada pelas imposições do tráfego rodoviário, que sentido histórico se encontra habilitada a transmitir ao seu habitante? O automobilista que se desloca da praça do Comércio ao Saldanha suspeita estar em trânsito num percurso carregado de memórias e espaços simbólicos consequentes a períodos determinantes do passado da cidade e do país?

Jacques Le Goff (2016 [1977-1982]) entende por monumento "tudo aquilo que pode evocar o passado, perpetuar a recordação". Espécie de herança que tem "como característica o ligar-se ao poder de perpetuação, voluntária ou involuntária, das sociedades históricas (é um legado à memória coletiva) e o reenviar a testemunhos" (Le Goff, 2016, pp. 535-536). Relaciona-se, assim, às formas de inscrição da memória - dirigindo-se ao presente e à posteridade. Ainda antes, Alois Riegl (2014 [1903]) define monumento como "obra criada pela mão do homem e elaborada com o objetivo determinante de manter sempre presente na consciência das gerações futuras algumas ações humanas ou destinos (ou a combinação de ambos)". Ele fala de monumentos volíveis (desempenham originalmente uma função prospectiva) e não volíveis (seu "valor de memória" é outorgado pelos pósteros). Riegl ainda aponta que apenas a partir na Renascença, com “a formação de um novo valor de memória” (Riegl, 2014, pp. 31 e 40), passa-se a apreciar monumentos (da Antiguidade) também por seu valor histórico, e não apenas por sua intenção recordativa.

De acordo com Henri Lefebvre (2000 [1974], p. 255), monumentos projetam uma imagem da comunidade, almejando o autorreconhecimento de seus membros. Como Le Goff, ele aponta sua intenção/aparência de escapar ao tempo (transcendendo à morte) e seus aspectos repressivo e coesivo: se controlam seu entorno, é para reunir a comunidade em torno deles. No centro de "um espaço no qual se reconhecem e se banalizam os traços da sociedade, os monumentos inscrevem uma transcendência, um alhures" (Lefebvre, 2008 [1970], pp. 29-30), proclamando outra dimensão nos percursos urbanos. Ponto forte de uma zona mais vasta, em sua leitura não se devem buscar significados determinados, e sim horizontes de sentidos variáveis no tempo.

Em uma acepção clássica, segundo Françoise Choay (2001 [1992], pp. 17-20), destaca-se a natureza afetiva: não se trata de apresentar "uma informação neutra, mas de tocar, pela emoção, uma memória viva”. Entretanto, tal 
função memorial/evocativa paulatinamente perde importância e o termo assume sentidos relacionados à grandeza, à beleza e à técnica. Contudo, a questão da memória se mantém central para a reflexão em pauta. Interessado pela temática, o escritor português Ramalho Ortigão (1934 [1914]), por exemplo, entende que o monumento, obra de arte pública, transmite uma mensagem "de gerações mortas a gerações que vivem", dando "ao povo um eterno e intangível tema de reflexão, de ensino, de simpatia e de concórdia absoluta". Nesse sentido, ele se opõe a monumentos que possam "suscitar desavenças e transmitir rancores" (ou "históricos pontapés") dos mortos aos vivos.

O tipo de monumento voluntário em causa pode ser entendido como um meio de simbolizar o privilégio conferido por uma comunidade a indivíduos, eventos ou conceitos exemplares. Quanto à "monumentomania" que marca a Europa da segunda metade de Oitocentos (Agulhon, 1998; 1978), o fenômeno se relaciona à quebra do monopólio da representação monumental (vinculada às mudanças políticas de fins do século XVIII), possibilitando monumentos a indivíduos de diferentes estratos - não por ascendência, mas por mérito (Bonnet, 1998; Ozouf, 2015 [1984]). Devido a seu papel na instrução e na propaganda, em um período de ampliação da participação política e da afirmação dos nacionalismos, inflaciona-se a proposta de estátuas, arcos triunfais e obeliscos; resultado e expressão de disputas (Berggren, 1999).

Para Fernando Catroga (1999, pp. 30-31), "as atitudes perante a morte que a modernidade foi gerando acentuam a monumentalidade funerária ao enfatizarem a memória como um segundo além imortalizador”. Na evocação de grandes homens, representifica-se sua imagem idealizada, posta a serviço das práticas identitárias da comunidade. Assim, pode-se falar, com Maurice Agulhon (1998), de uma pedagogia do grande homem esculpido. Além disso, dado que a "lembrança se inscreve numa experiência irreversível de tempo, ela é determinada pelo investimento mnésico dos vivos, o verdadeiro demiurgo dos deuses da memória" (Catroga, 1999, p. 31); depende do juízo dos homens do presente/futuro sobre os méritos dos homens do passado, entendidos como seus antepassados.

Ao pensar tais questões, pode-se, com Rui Martins (2010, p. 444), ponderar: "fatalmente, o passado tem futuros. O que fazer deles? O que fazem as sociedades políticas com eles? O que muda no modo como o fazem? Qual o reconhecimento da historicidade desses processos?". Para Fernando Nicolazzi (2010, p. 236), "o passado não chega ao presente apenas na expressão de uma herança legada. Ele é igualmente constituído enquanto tal a posteriori. 
[...] Na história e para os historiadores, é o presente quem fala do passado" - o que traz à tona os usos do passado (Turin, 2018). Se recuperar o passado é indispensável às comunidades, não é o passado que rege o presente, mas o presente que dele se vale da forma mais adequada - o que envolve recordar e esquecer (Todorov, 2000 [1995]; Connerton, 2008; Yerushalmi, 2017 [1988]; Pollak, 1989).

As efígies de Pombal em tela remontam a um grande intervalo. Monumentos simbólicos, intencionais e datados, podem ser percebidas como um esforço para inscrever, em espaços públicos e em suportes que se pretendem perenes, determinadas representações do marquês. Um esforço relacionado a usos desse passado, evocado e comemorado em áreas emblemáticas de uma cidade que ainda reclama uma herança pombalina. Podem, também, ser percebidas como documentos/monumentos do período em que são propostas, construídas e inauguradas, indiciando como então se lida com narrativas/memórias sobre Pombal - que seleção se opera em seu histórico, que mensagens se visa a transmitir a coetâneos e pósteros. Daí a importância de ressaltar o duplo sentido de monumento, atentando ao testemunho da/sobre a época de sua ereção e aos alhures ainda hoje evocados nos percursos quotidianos.

\section{NARRATIVAS DA LISBOA RECONSTRUÍDA}

Além de quem por ali passa a caminho de outras partes da cidade, a praça do Comércio (espaço monumental apontado como a mais importante praça de Lisboa) diariamente atrai muitos visitantes. Pintadas de amarelo, suas sóbrias alas de edifícios delimitam, com a Ribeira, uma grande área aberta e retangular, em cuja parte central se encontra, sobre um pedestal de pedra, a estátua equestre de D. José, em bronze. Envolvendo o espaço como braços abertos ao Tejo, os prédios pombalinos - nos quais se costumam destacar (na esteira do discurso do pombalismo) a harmonia e a aparente simetria como sinônimos de racionalidade e ordem - caracterizam-se por grandes arcadas contínuas, dois torreões paralelos e um arco triunfal, ao centro, enquadrando o início da rua Augusta, a mais emblemática da Baixa Pombalina (figura 2). 
Figura 2 - Panorama da praça do Comércio, a partir do Tejo. Turismo de Lisboa.

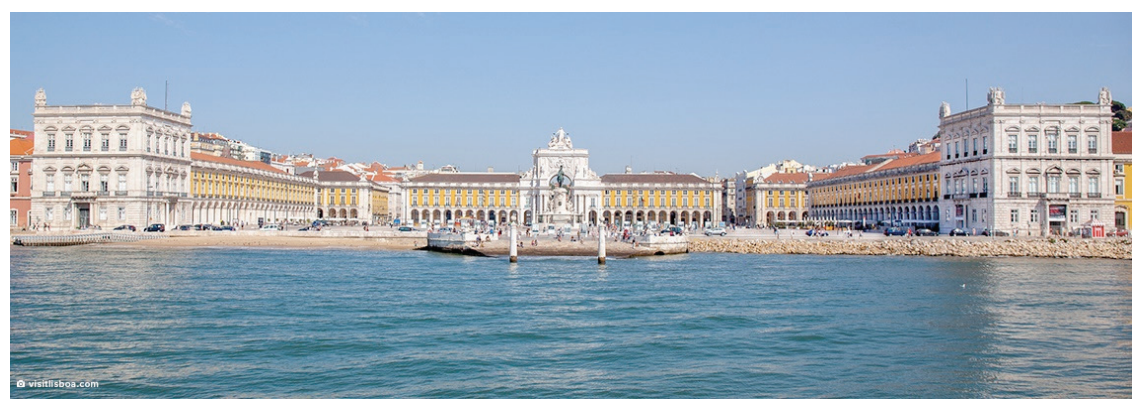

Fonte: Visit Lisboa... (s. d.).

Os edifícios que caracterizam a praça passaram por uma série de remodelações ao longo dos anos. Além de departamentos oficiais remanescentes, abrigam restaurantes, espaços multiuso, o Lisboa Story Centre e um núcleo do Museu de Lisboa - no local onde existiu, antes do terramoto, o Paço da Ribeira (figura 3), razão de a zona ser referida como Terreiro do Paço. Se no Centro de Interpretação Histórica e no museu se narram/apresentam acontecimentos lá decorridos no passado, nos dias que correm a praça é palco de atividades que congregam multidões: desde as festas do réveillon até o arraial pride, passando por protestos, concertos e celebrações esportivas.

Figura 3 - Terreiro do Paço. Azulejaria, mestre P. M. P., início do s. XVIII. Museu de Lisboa.

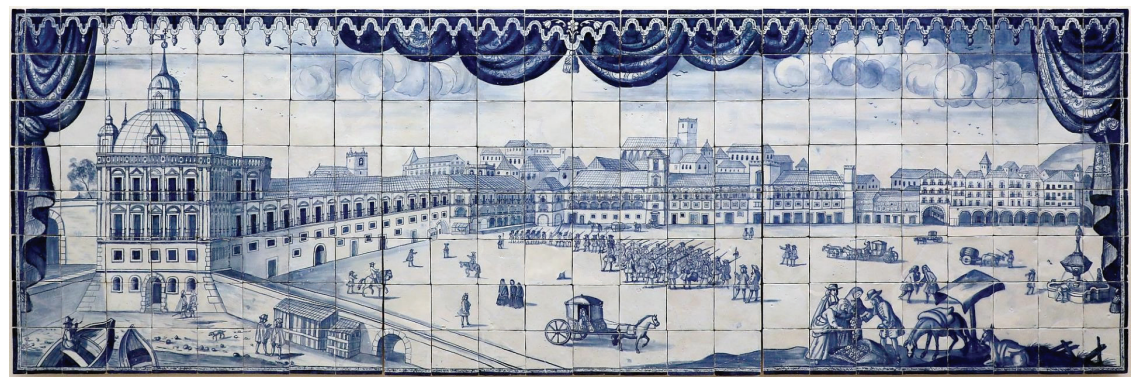

Fonte: Museu de Lisboa... (s. d.).

Destacados nas narrativas sobre a cidade, o terremoto e a reconstrução de Lisboa escapam ao foco deste texto. Como ressalta José-Augusto França (1989 [1977], pp. 99-101), contudo, a partir do cataclismo Pombal buscou impor "a 
'sua' capital, [fazendo-a] palco e cenário" para a sua ação. Muitos autores, apontando a catástrofe como ocasião por ele bem aproveitada, referem-se a suas medidas como um "terremoto político" - é o caso de Oliveira Martins (1882 [1879], pp. 172-183), para quem da hecatombe "nasceu o poder do marquês de Pombal [...]. Tudo havia a refazer, tudo se podia executar [...]. O terramoto fez-se, pois, homem e encarnou em Pombal, seu filho [...]. Não se reedificava Lisboa; erguia-se, no lugar da antiga, uma nova cidade" - com a anterior estrutura urbana em labirinto, que remontava aos períodos medieval e mourisco, substituída pelos traços homogêneos e retilíneos que caracterizam os planos pombalinos da Baixa (figura 4).

Figura 4 - Sobreposição de plantas da parte central da Baixa. As linhas escuras e vazadas representam a região antes do terremoto (tortuosa, labiríntica). As manchas em cinza representam as construções e os arruamentos retilíneos e homogêneos (racionais, iluministas) que caracterizam os planos pombalinos. Percebem-se a dimensão das mudanças empreendidas e a ideia de que se ergueu uma nova cidade, de traços modernos, no lugar da Lisboa medieval e mourisca.

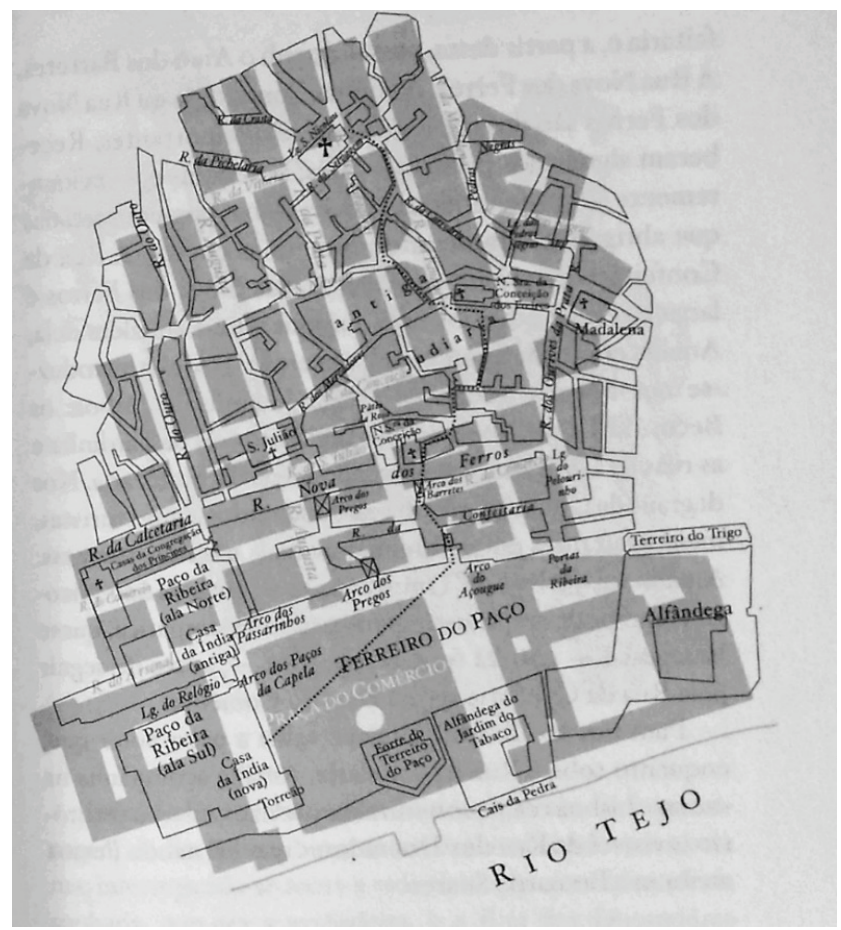

Fonte: Tavares (2015 [2005], p. 41). 
Central nos planos da cidade, a praça do Comércio traduz o que se convencionou chamar de espírito pombalino, coroando a reconstrução (Faria, 2005; 2008; 2012; Lousada, 2008). Já a cerimônia de inauguração da estátua (bem antes de as obras estarem concluídas) pode ser entendida como momento alto do governo (França, 1989 [1977]). Segundo Monteiro (2008 [2006], p. 316), culminava-se, então,

o esforço de autocelebração do reinado de D. José. A posteridade também não lhe negou os créditos [...]; permanece como a expressão mais emblemática e imponente de um tempo que nunca mais foi esquecido. O urbanismo pombalino perpetua-se, assim, como a imagem mais duradoura do reinado.

Ainda de acordo com o historiador, "se a Lisboa reconstruída já foi destacada como a corporização de uma 'cidade das Luzes', as luzes que a traçaram foram as da engenharia militar", com muitos precedentes - em espaços coloniais, em que se podiam "traçar povoações a régua e esquadro", mas também, mais pontualmente, no reino. O terremoto, com a quase total destruição da porção central da cidade, a que se seguiu o esforço, por parte do poder político, para impor "sem vacilações as soluções escolhidas", possibilitou que se iniciasse a reconstrução da capital9.

A ideia de que a reedificação se concluiu no período pombalino não corresponde, contudo, ao efetivo processo das obras, que se delongou no século XIX (Dias, 2012; Faria, 2008; Lousada, 2008). Como bem pontua França (1989 [1977], p. 102), entretanto, a cerimônia, organizada e presidida pelo marquês, "pôs (ou impôs) um ponto final no discurso", glorificando a empresa da reconstrução em um momento em que ainda havia muito a edificar; estando a praça "menos de meio terminada". No ritual, sucedido no espaço simbólica e efemeramente preenchido (com madeira, pano e gesso simulando os prédios e o arco ainda não construídos), cidade, praça e estátua se afirmavam uma homenagem ao monarca e a seu ministro - representado por um medalhão com sua efígie, no pedestal do monumento régio (Tavares, 2018).

Asseverou-se, então, a narrativa oficial acerca do reinado e também da capital pós-1755 - projeção de uma nação polida e civilizada (nas expressões caras a Pombal). As festas e seus impressos descritivos foram o auge do esforço de autopropaganda do pombalismo, indiciando a forma como pretendia ser visto pelos coetâneos e recordado pelos pósteros; vinculando, de maneira duradoura e eloquente, o monarca e o ministro à reedificação idealizada (Faria, 1994; 2008; 2009). Como indiciam as referências atuais à Lisboa reconstruída 
e ao indivíduo conhecido como seu reedificador, aparentemente se logrou, nesse quesito, convencer grande parte dos sujeitos de fins do século XVIII e também da posteridade - repetindo-se ideias difundidas sob o governo do marquês.

José Gramoza, contemporâneo ao período pombalino, assevera, em manuscrito encontrado e publicado em 1882 (quando, devido às comemorações do $1^{\circ}$ centenário fúnebre de Pombal, atualizaram-se debates em torno de seu passado), que Lisboa, na certeza de que o marquês foi "ativo instrumento" da reconstrução da cidade,

julgando prudentemente que quem pelos seus incomparáveis talentos e serviços tinha merecido toda a confiança e estimação do seu rei era congruente que o lugar que Sua Majestade lhe concedia e concede junto ao trono o ocupasse também no pedestal da real estátua, fez esculpir na frente dela a sua efígie de meio corpo, também de bronze.

Já para Camilo Castelo Branco (1982 [1882], p. 290), o medalhão se deveu a uma série de "patifarias que o marquês mandou praticar para se ver esculpido no monumento que ele a si mesmo erguia. Statua statuae [estátua da estátua], dizia o pasquim". Luz Soriano (1867, p. 142) afirma a tal respeito que, após a cerimônia, estava

simbolizada, por meio de um monumento público erigido na primeira praça de Lisboa, a onipotência governativa de Sebastião José de Carvalho e Melo; monumento que alguns dos contemporâneos da sua ereção mais julgaram ter sido realizado para nele se colocar o busto do marquês de Pombal do que para nele se pôr a estátua d'el-rei D. José, a respeito da qual alguns espíritos mordazes daquele tempo tiveram a ousadia de fazer e até mesmo de afixar, num dos pilares do enquadramento que cerca a referida estátua, o conceituoso pasquim, formado somente pelas seguintes palavras: statua statuae.

Gramoza (1882) recorda que a honra do ministro durou pouco. Morto o rei, "o povo miúdo", que conservava "no fundo do seu coração um grande rancor contra o marquês" (atribuindo "as atrocidades praticadas" durante o reinado a seu "mau coração"),

conspirava para que a dita efígie se arrancasse daquele lugar. Três dias se conservou naquele sítio uma grande quantidade do referido povo, clamando pelo dito arranco, atirando-lhe com pedras e imundícias. Do que tudo dando-se parte à 
rainha D. Maria I, determinou a mesma senhora que se tirasse o dito busto e que em seu lugar se fixasse uma tarja [...] com as armas do senado.

Para o conde de Carnota (1872 [1843], p. 298), os inimigos de Pombal "queriam fazer desaparecer da vista do povo tudo quanto pudesse contribuir para conservar a memória daquele ministro”. Na expressão de Pinheiro Chagas (1880, p. 147), "tiraram o retrato do marquês de Pombal da memória do terreiro do Paço". Contudo,

para demolirem a sua glória, não bastava arrancar o busto, era necessário arrasar de novo Lisboa, que ele erguera das ruínas mais bela do que nunca; era necessário derrubar a estátua que ele erigira ao rei que só fora grande porque o tivera ele ao seu lado, era necessário, enfim, arrancar as próprias armas de Lisboa, que tinham substituído o seu busto (Chagas, s. d., pp. 387-389).

$\mathrm{Na}$ altura do centenário de 1882, recuperou-se e se reproduziu em jornais um documento posterior ao desvalimento do marquês. No texto, afirma-se ser "geralmente reconhecido" que Pombal foi "o português que mais honrou a nação no século passado". A seguir, pondera-se sobre como se lidou com sua imagem, buscando explicar questionamentos à assertiva apresentada:

não é menos sabido que a inconstância dos tempos e o capricho dos homens pretenderam denegrir na pátria o conceito que nunca fora dela foi disputado a tão ilustre gênio e fizeram, com ingratidão incrível, desaparecer a sua imagem no centro daquela mesma cidade que ele tinha feito renascer das cinzas para ser uma das mais belas capitais da Europa (Marquês de Pombal VIII, 1882).

Não se trata apenas de como se abordou o histórico de Pombal; têm-se em vista, também, os percalços por que passou sua representação no centro da Lisboa reconstruída. No passo seguinte, apresenta-se uma tomada de posição visando à correção de tal postura; "querendo, ao mesmo tempo, tributar ao grande homem a justiça que lhe é devida e apagar os vestígios de uma ingratidão de que a geração presente rejeita a responsabilidade e desaprova o erro". Ou seja, distinguindo-se do modo como as gerações pretéritas lidaram com o ministro, busca-se, em nome da "geração presente", retificar-lhes tal falha, resgatando sua efígie - como legado às gerações futuras (Marquês de Pombal VIII, 1882).

O documento data de 10 de outubro 1833. Por meio dele, D. Pedro, primeiro imperador do Brasil (D. Pedro I, 1822-1831) e quarto monarca de seu 
nome em Portugal (D. Pedro IV, 1826) decreta, enquanto regente luso (duque de Bragança, 1831-1834):

hei por bem, em nome da rainha, que a imagem em bronze do marquês de Pombal [...], que havia sido arrancada do pedestal da estátua equestre de meu augusto avô, de quem fora tão leal servidor e de quem tão zelosamente procurava honrar a memória, seja reposta no mesmo lugar.

Ademais, manda que, "por lembrança do dia em que se praticou esse ato de justiça se lhe ajunte por baixo, em letras de bronze, a inscrição seguinte: 12 de outubro de 1833" - detalhe que combina, no monumento restaurado e atualizado, a celebração do marquês e a do regente, uma vez que era esse o dia de seu aniversário (Marquês de Pombal VIII, 1882).

Percebe-se como, antes do fim da guerra civil (1832-1834); antes de se findarem os confrontos com as tropas capitaneadas por D. Miguel (1828-1834), e logo após um governo liberal novamente ser instalado (encerrado o interregno absolutista) em Lisboa, D. Pedro se associou à imagem e ao legado pombalinos - repondo o conjunto e se aproveitando da ocasião para nele incluir nova inscrição. Também por tal gesto (além de iniciativas que atualizavam medidas políticas pombalinas), vinculou-se o regime que se reafirmava à recuperação e à celebração da memória de Pombal, valendo-se da reposição de sua imagem no principal espaço monumental da capital reedificada ${ }^{10}$. Daí se dizer que tinha sido "reservado para o governo liberal o anular essa afronta feita não só ao marquês de Pombal, mas à cidade de Lisboa e a todo o país" (Marquês de Pombal VIII, 1882).

Se as obras de reedificação de Lisboa chegaram a um fim muito tempo após a morte do marquês, somente em documentos da época e em algumas ilustrações coetâneas (figura 5) o espaço apresenta feição mais próxima à originalmente planejada - simulada em construções efêmeras levantadas para os festejos de 1775 (completando visual e temporariamente os prédios e o arco que delineiam a praça). Seu aspecto atual não corresponde totalmente, portanto, aos esboços pombalinos - o que não se deve (apenas) a vandalismos, catástrofes ou desgastes, mas (sobretudo) a interesses e desinteresses políticos e econômicos. 
Figura 5 - Praça do Comércio da Cidade de Lisboa, gravura de Gaspar Frois Machado. Museu de Lisboa.

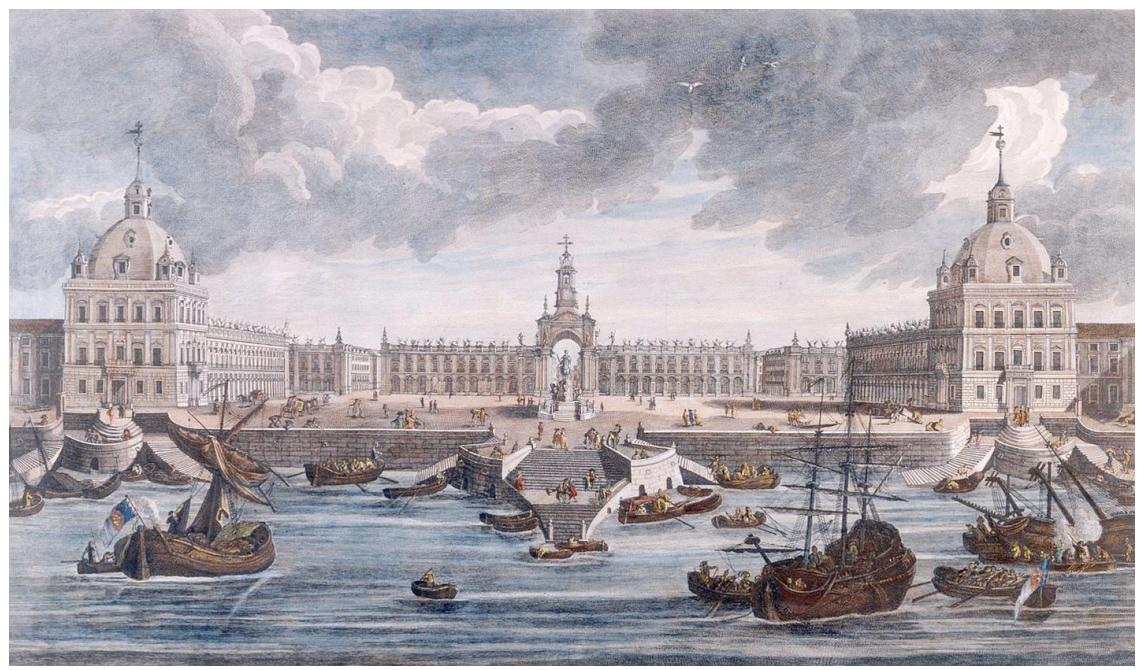

Fonte: Praça do Comércio... (s. d.).

Com o fim da ingerência de Pombal, alteraram-se, desde o princípio do reinado seguinte, as prioridades e o discurso do governo, o que se fez sentir no andamento e nos projetos das obras, e ainda nos usos do espaço ${ }^{11}$. A despeito da determinação régia que reduzia as atividades de construção em curso, os trabalhos prosseguiram - mas em um ritmo e com intenções diferentes, no que tocava ao programa monumental pombalino, que não correspondia aos interesses e às necessidades do novo reinado (Dias, 2012). Buscou-se concluir os edifícios iniciados e o cais das Colunas. $\mathrm{O}$ arco, pensado para coroar a estátua (emoldurando-a, reforçando a solenidade da praça), foi deixado de lado ${ }^{12}$.

$\mathrm{O}$ arco triunfal que hoje se vê se concluiu em 1873 e se inaugurou, após a colocação das estátuas, em 1875; sete anos antes do centenário pombalino e cem anos depois da inauguração da estátua do rei - apresentando, então, desenho distinto (França, 1989 [1977]; Faria, 2012). Trata-se de outro monumento: não mais o fechamento da praça do pombalismo/absolutismo, mas sim um símbolo do Liberalismo (figura 6). Não visando a coroar, simbolicamente, a estátua do monarca do Antigo Regime, tem por objetivo afirmar, no emblemático espaço monumental preexistente, reapropriado, o regime predecessor. Na década de 1840, definiu-se o novo projeto: um arco maciço e dominante, para cuja face se 
previram as nove esculturas acima referidas (Oliveira, [2011]). Dados os distúrbios que marcaram o período, o projeto tardou a ser concluído ${ }^{13}$.

Figura 6 - A estátua equestre, com o medalhão e o arco da rua Augusta. Fotografia de David Clay.

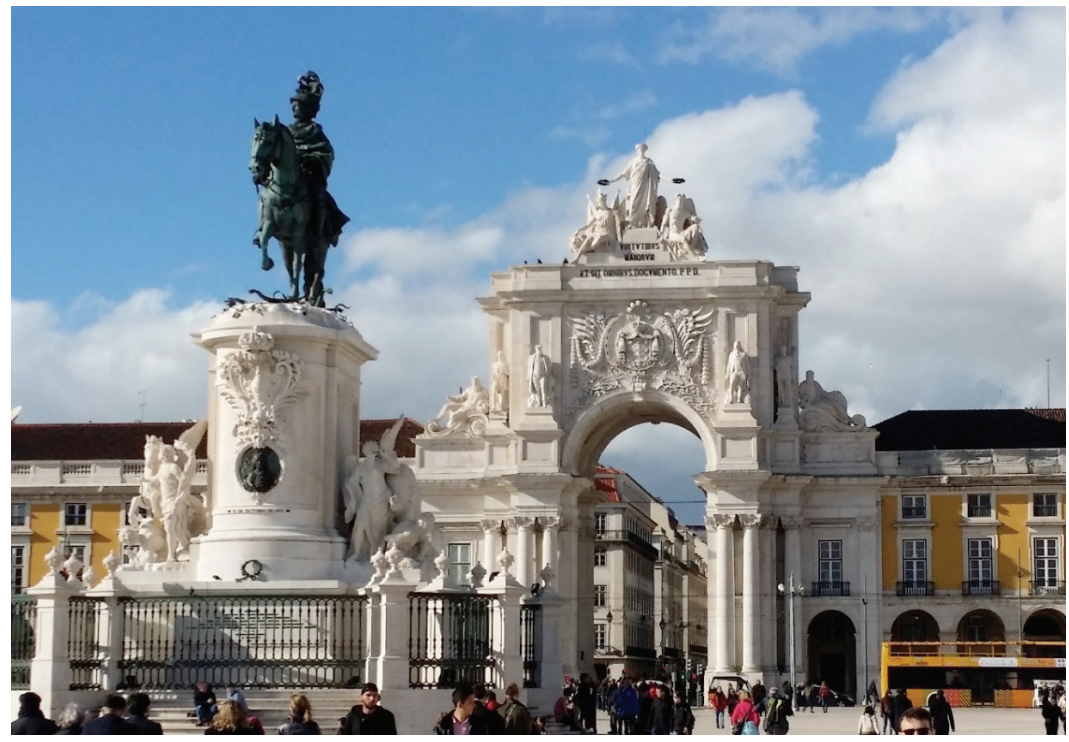

Fonte: Lisbon (s. d.).

No topo do arco, veem-se as enormes figuras alegóricas de virtudes liberais (a Glória coroando o Gênio e o Valor), acompanhadas da inscrição (em latim): "as virtudes dos maiores, para que sejam exemplo para todos. Erguido por subscrição pública”. Em seus extremos laterais, há alegorias dos rios Tejo e Douro (representando a unidade do país, a partir de Lisboa e do Porto - cidades decisivas na vitória liberal). Ao meio, veem-se esculturas menores de quatro indivíduos (celebrados não pelo nascimento, mas por seu serviço à pátria), representando períodos e conquistas históricos cujo encadeamento se dá a entender ter culminado no Liberalismo: Viriato (resistência aos romanos), Nuno Álvares Pereira (independência frente a Castela), Vasco da Gama (Descobrimentos) e Pombal.

A seleção dos homenageados nesse pequeno panteão não foi pacífica e a inclusão do marquês deu motivo a controvérsia (Matos, 1998). Afinal, a despeito de desde os momentos inaugurais do regime se recuperar sua figura, atuali- 
zando algumas de suas políticas e lhe prestando homenagens oficiais, seu nome se manteve fortemente ligado ao Antigo Regime. Em que pesem as críticas, contudo, o monumento assumiu, nesse quesito, a forma (liberal) planejada. Pombal segue representado no arco triunfal do Liberalismo; última peça da Baixa Pombalina edificada ao longo de muitos anos. Celebrado como responsável pela reconstrução, o marquês segura em suas mãos um rolo do papel que simboliza os planos da capital, sobre cujos escombros apoia os pés (figura 7).

Figura 7 - Estátua de Pombal. Pormenor em fotografia de Rehman Abubakr.

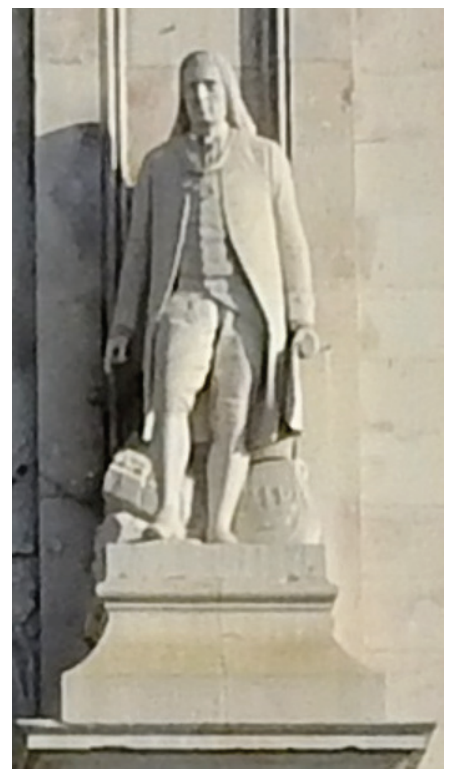

Fonte: Rua Augusta Arch (s. d.).

Na medida em que cumprem o propósito de preservar, inscrever e transmitir ao presente/futuro aspectos do passado, monumentos podem ser entendidos como lugares de memória (Nora, 2008 [1984-1992]). Para Catroga (2016 [2011], p. 22), contudo, "sua leitura só será re-suscitadora de memória se não se limitar à perspectiva gnosiológica e 'fria' (típica da leitura patrimonial, museológica e historiográfica) e se for afagada na partilha com outros". Daí a importância de comemorações, que supõem a evocação pública e a rememoração coletiva de aspectos de um passado ainda relevante para um grupo, trans- 
mitindo e preservando sua memória (Albuquerque Jr. 2019; Cottret; Henneton, 2010).

Há, por um lado, monumentos que, visíveis no espaço urbano, revelam-se invisíveis no quotidiano da cidade - não cumprindo, pois, a função de transmitir aos cidadãos lembranças de seu passado. Por outro lado, há monumentos que, a despeito daquilo a que Le Goff e Lefebvre se referem como intenção/ aparência de eternidade, como suposição/vontade de escapar ao tempo e à morte, não resistiram de pé ou integralmente - devido a calamidades, a obras públicas, a mudanças políticas, ou ao capricho, ao voluntarismo e ao justiçamento dos pósteros ${ }^{14}$. A tal respeito, Ramalho Ortigão (1882) afirma: "quando chegar a hora da justiça, não é a estátua do marquês de Pombal que se há de erigir; é a de D. José que se há de apear. No monumento do terreiro do Paço, o único que merece continuar a contemplar Cacilhas é o cavalo".

\section{UMA LISBOA POMBALINA}

Apesar do irônico vaticínio de Ortigão, D. José não apeia. Nesta breve reflexão, pontuaram-se modificações por que passou o espaço lisboeta. $\mathrm{Na}$ inauguração da estátua régia, afirmaram-se o discurso e a memória oficiais do pombalismo, a partir do conjunto monumental e de seu enquadramento. A despeito de se esperar que tal mensagem transcendesse a própria morte, o falecimento do rei marcou uma ruptura, que se expressou também no monumento. A retirada do medalhão se vinculou ao desvalimento e à desgraça do antes poderoso ministro - já encarado (em vida) como um passado negativo, passível de releitura e reenquadramento. Buscou-se, como desafronta pelas violências decorridas em seu ainda recente governo (julgadas abertamente, então, como de sua responsabilidade direta), suprimir do monumento régio e da memória do reino a efígie com que ele quisera comemorar e eternizar a sua figura. Tratou-se, pois, de uma forma peculiar de intervenção, apagando e reinscrevendo de forma distinta o passado ali representado.

Os protestos de 1777 foram, talvez, a única contestação direta ao conjunto monumental com consequência marcante (ainda que relativamente breve). Voltaram-se contra a representação do ministro, mas respeitaram a do monar$\mathrm{ca}$ - a despeito das ondas iconoclastas e das mudanças de regime que marcaram o período subsequente (Faria, 2012). No fim das contas, quando mais de uma vez chegou a "hora da justiça”, não se destruiu a estátua de D. José, mas primeiro se retirou, e depois se recuperou a efígie de seu célebre e polêmico ministro. A reposição, processo também apresentado como um ato de justiça/desafron- 
ta e reenquadramento de memória, associou-se a uma releitura de seu histórico; à reclamação de uma determinada herança pombalina a que então se queria vincular, política e simbolicamente, o Liberalismo. Tal processo assinalou outra alteração no monumento, a que a ocasião e a justificativa emprestaram um teor liberal. Ademais, inscreveu-lhe uma legenda em bronze; mensagem extemporânea, pontuando novo marco no conjunto, de tal modo restabelecido e reenquadrado (figura 8 ).

Figura 8 - O medalhão do marquês. Fotografia de Mike Steele.

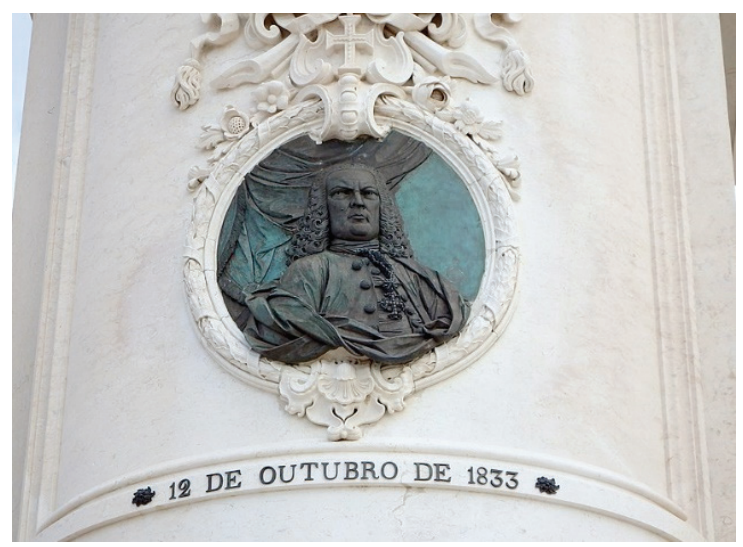

Fonte: In and Around the Praca do Commercio... (s. d.).

No entanto, se a retirada e a recolocação impactaram os coetâneos, na atualidade tais traços relativos à historicidade do monumento escapam à maior parte daqueles que visitam a praça-símbolo da Lisboa pombalina. Na zona térrea, o medalhão, acessível ao olhar dos transeuntes, passa-lhes praticamente despercebido. Situada no alto do arco da rua Augusta, mas um pouco abaixo de seu topo - de onde se observam a praça e o rio de um ponto de vista privilegiado, mas em sentido invertido em relação àquele planejado para o conjunto -, a estátua do marquês é ainda menos notada. Ambos são quase invisíveis no quotidiano; encarados como pormenores no amplo e movimentado espaço monumental pombalino, e não como monumentos intencionais em si mesmos (figura 9). Não cumprem devidamente, assim, sua função co-memorativa. 
Figura 9 - Praça do Comércio. Fotografia de Reino Baptista.

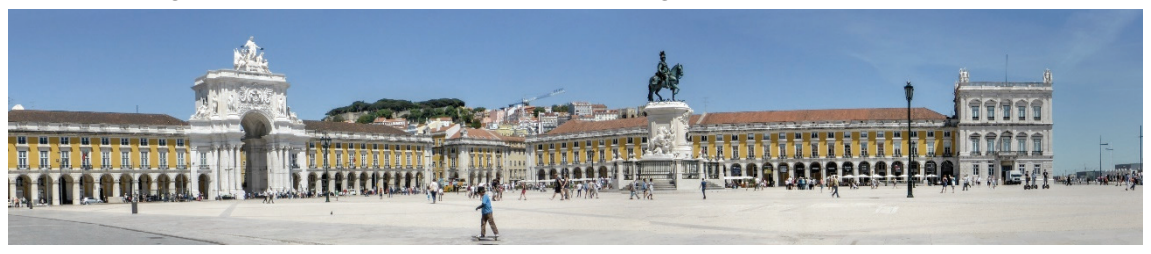

Disponível em: Praça do Comércio Central... (s. d.).

A ideia de uma Lisboa reconstruída/pombalina; a narrativa (pombalina) mais difundida acerca da reedificação da cidade (simbolizada na praça, celebrizada em fotografias, livros, anúncios turísticos, postais...), contudo, revela-se um dos mais eloquentes monumentos a/de Pombal - como demonstra o discurso mobilizado nos textos de divulgação do Lisboa Story Centre e nos projetos para comprovar o Valor Universal Excepcional da Lisboa Pombalina, elevando-a a Patrimônio Mundial da UNESCO. Já a estátua na Rotunda, “inaugurada” em 1882 (Liberalismo) e concluída apenas em 1934 (Estado Novo), ela se impõe, enorme, incontornável e altiva, em outro espaço monumental, que recebe do marquês seu topônimo mais usual. Trata-se de uma homenagem/comemoração distinta; um documento/monumento diferente - assunto para outro percurso.

\section{REFERÊNCIAS}

ABREU, Luís Machado de. Ensaios anticlericais. Lisboa: Roma Editora, 2004.

AGULHON, Maurice. Nouveaux propos sur les statues de "grands hommes" au XIXe siècle. Romantisme, n. 100, pp. 11-16, 1998.

AGULHON, Maurice. La "statuomanie" et l'histoire. Ethnologie français, t. 8, n. 2-3, pp. 145-172, 1978.

ALBUQUERQUE JR., Durval Muniz de. O tecelão dos tempos: novos ensaios de teoria da História. São Paulo: Intermeios, 2019.

ALMEIDA, Fabrice. Musée d'histoire, histoire dans les musées. Vingtième siècle, v. 37, pp. 148-150, 1993.

ARANTES, Otília Beatriz Fiori. Urbanismo em fim de linha. São Paulo: EdUSP, 1998. ATL - Associação Turismo de Lisboa. s. d. Disponível em: https://www.visitlisboa.com/ pt-pt/sobre-o-turismo-de-lisboa Acesso em: 10 nov. 2019.

AZEVEDO, João Lúcio de. O marquês de Pombal e a sua época. Lisboa: Clássica Editora, 1990 [1909].

BEIGUELMAN, Giselle. Memória da amnésia: políticas do esquecimento. São Paulo: Edições SESC, 2019. 
BERGGREN, Lars. The "monumentomania" of the Nineteenth Century: causes, effects and problems of study. In: REININK, Adriaan Wessel; STUMPEL, Jeroen (Eds.). Memory \& oblivion: proceedings of the XXIXth International Congress of the History of Art, held in Amsterdam, 1-7 September 1996. Boston: Kluwer Academic Publishers. 1999. pp. 561-566.

BLACK, Graham. Museums, memory and history. Cultural and Social History, v. 8, i. 3, pp. 415-427, 2011.

BONNET, Jean-Claude. Naissance du Panthéon: essai sur le culte des grands hommes. Paris: Fayard, 1998.

BRAGA, Joana; GUTERRES, António Brito. Lisboa Histórica, Cidade Global. As intervenções públicas de requalificação urbana, os discursos que as sustentam e suas implicações. Jornal Arquitectos, n. 255, 2017.

[CARNOTA, conde da] SMITH, John A. Memórias do Marquez de Pombal: contendo extractos dos seus escriptos e da correspondencia diplomatica inedita existente em differentes secretarias d'estado. Lisboa: 1872 [1843].

CASTELO BRANCO, Camilo. Perfil do Marquês de Pombal. Porto: Lello \& Irmão, 1982 [1882].

CATROGA, Fernando. O céu da memória: cemitério romântico e culto cívico dos mortos em Portugal, 1756-1911. Coimbra: Minerva, 1999.

CATROGA, Fernando. Os passos do homem como restolho do tempo: memória e fim do fim da história. Coimbra: Almedina, 2016 [2011].

CHAGAS, Manuel Pinheiro. História Alegre de Portugal: leitura para o povo e para as escolas. Lisboa: David Corazzi, 1880.

CHAGAS, Manuel Pinheiro. História de Portugal (popular e ilustrada). Vol. X. Rio de Janeiro: Escriptorio da Empreza, s. d.

CHOAY, Françoise. A Alegoria do patrimônio. São Paulo: Unesp, 2001 [1992].

CANDIDATURAS À UNESCO: CML - Câmara Municipal de Lisboa. [Baixa Pombalina de Lisboa] Formulário; [Lisboa Histórica] Proposta; [Lisboa Histórica, Cidade Global] Formulário. 2017. Disponível em: http://www.cm-lisboa.pt/viver/urbanismo/candidaturas-a-unesco. Acesso em: 29 dez. 2019.

CONNERTON, Paul. Como as sociedades recordam. Oeiras: Celta, 1999 [1989].

CONNERTON, Paul. Seven types of forgetting. Memory Studies, vol. 1, n. 1, pp. 59-71, 2008.

COTTRET, Bernard; HENNETON, Lauric. La commémoration, entre mémoire prescrite et mémoire proscrite. In: Du bon usage des commémorations: Histoire, mémoire et identité, XVI-XXIe siècle [en ligne]. Rennes: Presses Universitaires de Rennes, 2010. pp. 7-24.

DIAS, Cristina. Real Praça do Comércio: momentos de construção e ocupação de D. José a D. João VI. In: FARIA, Miguel Figueira de (Coord.). Do Terreiro do Paço à 
Praça do Comércio: história de um espaço urbano. Lisboa: Imprensa Nacional Casa da Moeda, 2012. pp. 271-302.

FARIA, Miguel Figueira. 6 June, the king's birthday present: an insight into the history of royal monuments in Portugal at the end of the Ancien Régime. In: CHASTEL-ROUSSEAU, Charlotte (Ed.). Reading the Royal Monument in Eighteenth-Century Europe. Farnham: Ashgate, 2009. pp. 71-91.

FARIA, Miguel Figueira de. A estátua equestre, in absentia principis e o rei escondido. In: FARIA, Miguel Figueira de (Coord.). Do Terreiro do Paço à Praça do Comércio: história de um espaço urbano. Lisboa: Imprensa Nacional Casa da Moeda, 2012. pp. 157-227.

FARIA, Miguel Figueira de. Lisbonne, la place royale du Commerce. In: De l'Espirit des Villes: Nancy et l'Europe urbaine au siècle des Lumières, 1720-1770. Nancy: Éditions Artlys, pp. 236-241, 2005.

FARIA, Miguel Figueira de. O modelo praça/monumento central na evolução urbanística da cidade de Lisboa. Actas do Colóquio Lisboa Iluminista e o seu Tempo. Lisboa: UAL, 1994. pp. 51-96.

FARIA, Miguel Figueira de (Coord.). A Praça Real do Tejo. In: FARIA, M. F. (Org.). Praças Reais. Passado, presente e futuro. Lisboa: Horizonte, 2008. pp. 203-227.

FERREIRA, Claudino. Cultura e regeneração urbana: novas e velhas agendas da política cultural para as cidades. Revista Tomo, n. 16, pp. 29-56, 2010.

FOSTER, Hal. Museus sem fim. Piauí, n. 105, 2015.

FRANÇA, José-Augusto. A reconstrução de Lisboa e a arquitectura pombalina. Lisboa: ICLP, 1989 [1977].

GOSTAVA DE PERGUNTAR ALGUMA coisa a Vasco da Gama? Time Out, Lisboa. 20 abr. 2017. Disponível em: https://www.timeout.pt/lisboa/pt/blog/gostava-de-perguntar-alguma-coisa-a-vasco-da-gama-042017. Acesso em: 10 nov. 2019.

GRAMOZA, José Pedro Ferrás. Successos de Portugal: Memorias Historicas Politicas e Civis. Lisboa: Diário da Manhã, 1882.

HALBWACHS, Maurice. A memória coletiva. São Paulo: Centuro, 2013 [1950].

HISTORICAL LISBON, Global City; UNESCO. Disponível em: https://whc.unesco. org/en/tentativelists/6208/. Acesso em: 29 dez. 2019.

IN AND AROUND THE PRACA DO COMMERCIO in the morning: Wikimedia Commons. s. d. Disponível em: https://commons.wikimedia.org/wiki/File:In_and_ Around_the_Praca_do_Commercio_in_the_morning_(28577521638).jpg. Acesso em: 5 fev. 2020.

KNAUSS, Paulo. Quais os desafios dos museus em face da história pública? In: MAUAD, Ana Maria; SANTHIAGO, Ricardo; BORGES, Viviane Trindade (Orgs.). Que história pública queremos? São Paulo: Letra e Voz, 2018. pp. 141-146.

LEFEBVRE, Henri. La production de l'espace. Paris: Anthropos, 2000 [1974].

LEFEBVRE, Henri. A revolução urbana. Belo Horizonte: UFMG, 2008 [1970]. 
LE GOFF, Jacques. História e Memória. Campinas: Unicamp, 2016 [1977-1982].

LISBOA STORY CENTRE, MEMÓRIAS alfacinhas high tech, Público, Lisboa. 8 set. 2012. Disponível em: https://www.publico.pt/2012/09/08/jornal/lisboa-story-centre-memorias-alfacinhas-high-tech-25170000. Acesso em 10 nov. 2019.

“LISBOA STORY CENTRE” INAUGURADO a 11 de Setembro, Correio da Manhã, Lisboa. 3 set. 2012. Disponível em: https://www.cmjornal.pt/cultura/detalhe/lisboa-story-centre-inaugurado-a-11-de-setembro. Acesso em: 10 nov. 2019.

LISBON: Wikimedia Commons. s. d. Disponível em: https://commons.wikimedia.org/ wiki/File:Lisbon_(25882379286)_(cropped).jpg. Disponível em: 5 fev. 2020.

LOUSADA, Maria Alexandre. Praça e sociabilidade: práticas, representações e memórias. In: FARIA, Miguel Figueira de (Coord.). Praças Reais: passado, presente e futuro. Lisboa: Horizonte, 2008. pp. 45-56.

MARTINS, Rui Cunha. Discurso de Elogio do Doutorando John G. A. Pocock. Biblios, n. 08, pp. 443-453, 2010.

MARQUÊS de Pombal VIII. Gazeta de Notícias, Rio de Janeiro, 6 abr. 1882.

MATEUS, João Mascarenhas. Imagem e memória da Baixa Pombalina. In: CARIA, H. (Coord.). Baixa Pombalina: 250 anos em imagens. Lisboa: CML, pp. 10-18, 2004a. MATEUS, João Mascarenhas. Resultados e conclusões. In: MATEUS, J. M. (Ed.). A Baixa Pombalina e sua importância para o Património Mundial. Comunicações... Lisboa: CML, pp. 104-124, 2004b.

MATOS, Sérgio Campos. Historiografia e memória nacional no Portugal do século XIX (1846-1898). Lisboa: Colibri, 1998.

MATOS, Sérgio Campos. Pombal, da Revolução Liberal ao Estado Novo. In: SILVA, João Paulo Pereira (Coord.). Pombal e o seu tempo. Sintra: Caleidoscópio, 2010. pp. 17-29.

MEMÓRIAS da Cidade - O que é?, Lisboa Story Centre. s. d. Disponível em: https:// www.lisboastorycentre.pt/pt/content/mem $\% \mathrm{C} 3 \% \mathrm{~B} 3$ rias-da-cidade-o-que-\%C3\%A9 . Acesso em 10 nov. 2019.

MENEZES, Ulpiano Toledo Bezerra. Do teatro da memória ao laboratório da História: a exposição museológica e o conhecimento histórico. Anais do Museu Paulista, v. 2, n. 1, pp. 9-42, 1994.

MONTEIRO, Nuno Gonçalo. D. José: na sombra de Pombal. Lisboa: Temas e Debates, 2008 [2006].

MUSEU DE LISBOA: Acervo. s. d. Disponível em: http://acervo.museudelisboa.pt/ multimediaNET/2021/07/web/151539.jpg. Disponível em: 30 out. 2021.

NICOLAZZI, Fernando. A História entre tempos: François Hartog e a conjuntura historiográfica contemporânea. História: Questões e Debates, n. 53, n. 2, pp. 229-257, 2010.

NORA, Pierre. Pierre Nora en Les lieux de mémoire. Montevideo: Trilce, 2008 [1984-1992]. 
OLIVEIRA, Paulo Martins. O arco da rua Augusta - monumento do Liberalismo. [s/e] [2011]. Disponível em: https://www.academia.edu/8579559/_P_O_Arco_da_Rua_ Augusta_Monumento_do_Liberalismo. Acesso em 10 nov. 2019.

OLIVEIRA MARTINS, Joaquim Pedro. História de Portugal. T. II. Lisboa: Bertrand, 1882 [1879].

ORTIGÃO, José Duarte Ramalho. As Farpas: cronica mensal da prática, das letras e dos costumes, $4^{\text {a }}$ s., n. 1, jun/jul, 1882.

ORTIGÃO, José Duarte Ramalho. Vinte anos depois. Um artigo de Ramalho Ortigão acerca de um projecto de monumento ao marquês de Pombal. Diário de Lisboa, Lisboa, 19 mai. 1934 [1914].

OZOUF, Mona. Le Panthéon: lécole normale des morts [1984]. De Révolution en République. Paris: Gallimard, 2015. pp. 313-336.

PAULO, Heloisa. Mito e História: as oposições na historiografia portuguesa. In: RIBEIRO, M. T. (Coord.) Outros Combates pela História. Coimbra: Universidade de Coimbra, 2010. pp. 167-174.

PEIXOTO, Paulo. A corrida ao status de patrimônio mundial e o mercado urbano de lazer e turismo. Veredas - Revista Científica de Turismo, v. 1, n. 1, pp. 23-45, 2002.

PEIXOTO, Paulo. A cidade performativa na era da economia das experiências. In: FORTUNA, Carlos et al. (Orgs.). Cidade e Espetáculo: a cena teatral luso-brasileira contemporânea. São Paulo: EDUC, 2013. pp. 141-151.

PEREIRA, José Esteves. Identidade Nacional. Do reformismo absolutista ao liberalismo. In: BETHENCOURT, Francisco; CURTO, Diogo Ramada. A memória da nação. Lisboa: Sá da Costa, 1991. pp. 425-438.

POLLAK, Michael. Memória, esquecimento, silêncio. Estudos Históricos, Rio de Janeiro, v. 2, n. 3, pp. 3-15, 1989.

PRAÇA DO COMÉRCIO da Cidade de Lisboa. s. d. Disponível em: http://acervo. museudelisboa.pt/multimediaNET/2019/10/web/115491.jpg. Acesso em: 05 fev. 2020.

PRAÇA DO COMÉRCIO CENTRAL and North wing: Wikimedia Commons. s. d. Disponível em: https://commons.wikimedia.org/wiki/File:Pra\%C3\%A7a_do_ Com\%C3\%A9rcio_Central_and_North_wing.jpg. Acesso em: 5 fev. 2020.

RICOEUR, Paul. A memória, a história, o esquecimento. Campinas: Editora da Unicamp, 2018 [2000].

RICOEUR, Paul. Tempo e narrativa: 1 - A intriga e a narrativa histórica. São Paulo: Martins Fontes, 2010 [1983].

RIEGL, Alois. O culto moderno dos monumentos: a sua essência e a sua origem. São Paulo: Perspectiva, 2014 [1903].

RUA AUGUSTA ARCH. s. d. Disponível em: https://commons.wikimedia.org/wiki/ File:Rua_Augusta_Arch_-_April_2019.jpg. Acesso em: 5 fev. 2020. 
SÁNCHEZ, Fernanda Ester. A reinvenção das cidades para um mercado mundial. Chapecó: Argos, 2010 [2003].

SERRÃO, João Vicente. Pombalismo: sistema político e funcionamento institucional. In: COSTA, Fernando Marques da et al. (Orgs.). Do Antigo Regime ao Liberalismo (1750-1850). Lisboa: Veja, 1989. pp. 11-21.

SERRÃO, Joel. Repensar Pombal. In: SANTOS, Maria Helena Carvalho dos (Coord.). Pombal Revisitado. Vol. II. Lisboa: Estampa, 1984. pp. 351-359.

SORIANO, Simão José da Luz. História do reinado de El-Rei Dom José e da administração do marquez de Pombal: precedida de uma breve notícia dos antecedentes reinados, a começar no de el-rei D. João IV, em 1640. T. II. Lisboa: Typographia Universal de T. Quintino Antunes, 1867.

TAVARES, Rui. O censor iluminado: ensaio sobre o pombalismo e a revolução cultural do século XVIII. Lisboa: Tinta da China, 2018.

TAVARES, Rui. O pequeno livro do Grande Terramoto: ensaio sobre 1755. Lisboa: Tinta da China, 2015 [2005].

TODOROV, Tzvetan. Los abusos de la memoria. Barcelona: Paidos, 2000 [1995].

TORGAL, Luis Manoel Soares dos Reis. Pombal perante as ideologias tradicionalistas e católicas. In: SANTOS, Maria Helena Carvalho dos (Coord.). Pombal Revisitado. Vol. I. Lisboa: Estampa, 1984. pp. 131-157.

TRAVERSO, Enzo. El pasado, instrucciones de uso: historia, memoria, política. Madri; Barcelona: Marcial Pons, Ediciones Jurídicas y Sociales, 2007 [2000].

TURIN, Rodrigo. Entre o passado disciplinar e os passados práticos: figurações do historiador na crise das humanidades. Tempo, v. 24, n. 02, pp. 186-205, 2018.

TURISMO de Lisboa. Disponível em: https://www.visitlisboa.com. Acesso em: 05 fev. 2020.

TURISMO de Portugal. s. d. Disponível em: https://www.turismodeportugal.pt/pt. Acesso em: 10 nov. 2019.

UNESCO, World Heritage Convention. Convention Text. Convenção para a Proteção do Património Mundial, Cultural e Natural [1972]. Disponível em: https://whc. unesco.org/archive/convention-pt.pdf. Acesso em: 29 dez. 2019.

UNESCO, World Heritage List Nominations. s. d. Disponível em: https://whc.unesco. org/en/nominations. Acesso em: 29 dez. 2019.

POMBALINE LISBON; UNESCO. Disponível em: https://whc.unesco.org/en/tentativelists/6226/. Acesso em: 29 dez. 2019.

PROGRAMA para escolas, Lisboa Story Centre. s. d. Disponível em: https://www. lisboastorycentre.pt/pt/content/programa-para-escolas-201415. Acesso em: 10 nov. 2019.

VERHEIJ, Gerbert. Monumentos coloniais em tempos pós-coloniais. A estatuária de Lourenço Marques. CONGRESSO HISTÓRIA DA ARTE PORTUGUESA. IV, 2014. IV Congresso de história da Arte Portuguesa: Actas, APHA, 2014. pp. 36-45. 
VISÃO - Posicionamento - Promessa, Lisboa Story Centre. s. d. Disponível em: https:// www.lisboastorycentre.pt/pt/content/vis\%C3\%A3o-posicionamento-promessa. Acesso em: 10 nov. 2019.

VISIT LISBOA: Galeria. Disponível em: https://www.visitlisboa.com/pt-pt/galleries/ galeria. Acesso em: 5 fev. 2020.

YERUSHALMI, Yosef Hayim. Reflexões sobre o esquecimento. In: YERUSHALMI, Y. H. et al. Usos do esquecimento: conferências proferidas no colóquio de Royaumont. Campinas: Unicamp, 2017 [1988]. pp. 9-28.

\section{NOTAS}

${ }^{1}$ Privada e sem fins lucrativos, a Associação Turismo de Lisboa (ATL) é a agência regional de promoção turística dirigida pela Câmara Municipal de Lisboa (CML) (cf. ATL, s. d.). Já o Turismo de Portugal, integrado ao Ministério da Economia, é a autoridade turística nacional (cf. Turismo de Portugal, s. d.).

${ }^{2}$ Propõe-se "o encontro ao vivo com personagens que protagonizam capítulos da história da cidade de Lisboa. As figuras testemunham na primeira pessoa os hábitos e as escolhas que tomaram e que influenciaram o percurso da cidade e do país".

${ }^{3}$ Segundo a Convenção do Patrimônio Mundial (UNESCO, [1972]), o Comitê do Patrimônio Mundial estabelece, a partir da Lista Indicativa apresentada pelos Estados-parte, a Lista do Patrimônio Mundial. O conceito de Valor Universal Excepcional fundamenta os bens inscritos (UNESCO, s. d.).

${ }^{4}$ A empreitada parte da CML em 2002. A candidatura é validada em 2004, mas são necessários instrumentos de gestão e salvaguarda. Em 2016, apresenta-se nova candidatura, mais abrangente, que também não avança (Candidaturas à UNESCO, 2017; Pombaline Lisbon, s. d.; Historical Lisbon..., s. d.). Busca-se, assim, a "materialização de uma visão de cidade cosmopolita que oferece sua singularidade, entretanto recodificada para assegurar o seu reconhecimento". Pensa-se a cidade como uma marca, competindo "pela sedução de turistas e pela atenção do investimento financeiro internacional. Mais ainda, convocam a dimensão patrimonial do ambiente urbano, enfatizando momentos heroicos da sua história, exibindo a singularidade da cultura popular que a caracteriza, como mais-valia nessa competição intercidades" (Braga; Guterres, 2017).

${ }^{5} \mathrm{~A}$ respeito dos efeitos da chamada economia da experiência nos espaços urbanos e museológicos, ver Foster, 2015; Peixoto, 2013.

${ }^{6} \mathrm{Na}$ segunda candidatura à UNESCO também se afirma: "depois do terramoto de 1 de novembro de 1755, a sua reconstrução sob o governo do marquês de Pombal serviu, na Europa e no mundo, para a criação da primeira cidade moderna do Ocidente" (Candidaturas à UNESCO, 2017 [formulário]).

${ }^{7}$ Segundo Paulo Peixoto (2002, pp. 23-24), o "status de patrimônio se apresenta como uma 
mais-valia" em três domínios: 1) "vetor de estratégias de marketing urbano"; 2) "trunfo nas campanhas que procuram captar os fluxos de turismo cultural e patrimonial"; 3 ) "elemento retórico de legitimação e de contestação das políticas de transformação das paisagens urbanas".

${ }^{8}$ Acerca da tensão memória-história, ver: Traverso, 2007 [2000].

${ }^{9}$ Costumam-se destacar, dentre os colaboradores do marquês, Eugênio dos Santos e Manuel da Maia (engenheiros envolvidos nos planos da Baixa) e também Joaquim Machado de Castro (escultor do monumento régio). Ainda que esses nomes se encontrem em documentos de época, livros de história e museus, no discurso mais difundido sobre a reconstrução o protagonismo cabe a Pombal.

${ }^{10}$ Os liberais reclamavam, havia muito, uma herança pombalina - atualizando tópicos como reformas políticas, regalismo e anticlericalismo/antijesuitismo. A este respeito, ver Abreu, 2004; Matos, 2010; Torgal, 1984.

${ }^{11}$ José Esteves Pereira (1991, p. 428) fala de uma "cidade interrompida, do risco de Razão que é esquecido". Em 1777, D. Maria I fez retirar o medalhão, suspender grande parte das obras e desmanchar construções efêmeras que desde 1775 compunham/simulavam o cenário idealizado. Em 1780, ordenou a desocupação e a adaptação de edifícios que delineavam a praça para a família real neles habitar, retornando à região do Paço.

${ }^{12}$ Geralmente percebida como um monumento pombalino bem acabado, a praça, para Faria (2008, p. 216), é um "remate inacabado [...], sendo na expressão das suas visíveis contradições muito mais um 'rosto' do que uma 'máscara', traduzindo nas várias fases da sua arrastada construção os avanços e recuos das situações pombalina e mariana de que o non-finito do programa monumental é testemunho esclarecido".

${ }^{13}$ As colunas já estavam erguidas em 1815 . O concurso para definir o projeto liberal decorreu em 1843, delongando-se, entretanto, as obras. Em fins da década de 1860, o arco estava fechado, mas o monumento não estava concluído; faltava o remate, com as esculturas, iniciado em 1873.

${ }^{14}$ Gerbert Verheij (2014, p. 37), refletindo sobre a destruição e a remoção de estátuas, fala de uma "manifestação involuntária da própria historicidade na obra". Deslocadas do contexto original, evidenciam mudanças e deslocamento de sentido. Por vezes, inscrevem/evocam no espaço público um passado/uma mensagem que não mais se quer preservar/recordar, e sim esquecer/substituir/destruir. Ver ainda Beiguelman, 2019.

Artigo submetido em 4 de agosto de 2021.

Aprovado em 20 de outubro de 2021. 